\title{
STORMPAY PAVEMENT USING DIFFERENT WHEEL LOADS
}

\author{
* Elsa Eka Putri ${ }^{1}$, Liew, S.C. ${ }^{2}$, Mohammad Abdul Mannan², Ron Aldrino Chan @ Ron Buking ${ }^{2}$, Larry Silas \\ Tirau $^{2}$ \\ ${ }^{1}$ Engineering Faculty, University of Andalas, Padang, Indonesia; \\ ${ }^{2}$ Engineering Faculty, Universiti Malaysia Sarawak, Malaysia
}

Corresponding Author, Received: 06 Oct. 2021, Revised: 01 Nov. 2021, Accepted: 09 Jan. 2022

\begin{abstract}
Distress models are required during design to ensure the pavement have a longer service life that is conducted for different axle weight. This research addresses by modeling and analyzing StormPav pavement under various wheel loads to ensure pavement structures can withstand these loads. StormPav pavement is made up of precast concrete with Grade 50, which is also known as the innovative IBS Green Pavement, which has a combination of structural, environmental and economic advantages. The analysis of mechanistic behavior for different structures of pavements and mechanistic behavior of precast StormPav pavements using different wheel loads. WinJULEA and KENPAVE are software used for this research for modeling the real scenario to obtain the deflection, stress, strain and stress of each layer of pavement. It is found that total ESAL increases when there is a heavier truck acting on top of the pavement, and precast StormPav pavement receives the lowest total ESAL compared to flexible and rigid pavement. Among various types of pavements, precast StormPav has lesser maximum deflection, which had $65.11 \%$ lesser compared to the flexible pavement due to its largest elastic modulus. Besides, when there is loading from a 24-tonne truck acting on top of the precast StormPav pavement, total deflection is $0.761 \mathrm{~mm}$ and increases $0.064 \mathrm{~mm}$ $(8.345 \%)$ when there is loading change to 26-tonne truck, as precast StormPav pavement is made up of concrete grade 50, which can resist to heavier loading. Precast StormPav pavements have the highest maximum allowable load repetitions to prevent fatigue cracking due to their increased flexural strength, which enables them to withstand greater stresses above the structure. As a result, it can be concluded that precast StormPav pavement is a viable alternative to the pavement because it requires less time for construction and sustains less damage when subjected to heavier loads.
\end{abstract}

Keywords: Distress, StormPav, KENPAVE, WinJULEA, Wheel Load

\section{INTRODUCTION}

The two most common pavement structures in the road industry are flexible and rigid pavement. There is a pavement type selection process (PTS) that transportation agencies, including Jabatan Kerja Raya (JKR), can follow when selecting appropriate pavement structures for a particular project. The PTS process involves the detailed analysis of various pavement design factors, such as design volume, material properties and environment [1]. Besides, the initial cost, costing for overall annual maintenance, and other costings during its service life cost also play an important role in the pavement selection process. Each type of these pavement structures is different compared to each other in several aspects. This involves the design procedure, period for service life, deterioration (distress models), construction, and rehabilitation options [2].

The pavement can be evaluated by analyzing the road pavement's performance. Among the numerous types of distress, the most significant one that has a significant impact on pavement performance is fatigue cracking and rutting [3]. Fatigue cracking occurred as a result of horizontal tensile strain at the asphalt layer's base. Meanwhile, excessive vertical compressive strain at the subgrade layer's top will result in permanent deformation or rutting of the pavement structures. In pavement design, fatigue and rutting modes of distress must be considered and balanced to fully utilize the pavement material in an economically feasible design [4].

Apart from that, the drainage system incorporated into the pavement structure plays a significant role in the pavement's performance [3]. The drainage system is responsible for the management of existing watercourses, the removal of water from pavement structures, and the control of subsurface water in pavement structures, particularly rainwater runoff. As a result, it is critical to ensure that the pavement is equipped with an effective drainage system that can service the road and drain water caused by rain floods. Moreover, there is insufficient filtering vegetation 
and absorbent soil surface, which disrupts absorption and increases runoff volume, hence increasing the frequency of flooding, especially in the fast-developing area [5]. Pervious pavement, precast StormPav pavement, should be adopted widely in the road industry as it has a better drainage system compared to impervious pavement.

There has been a rise in road construction projects in Sarawak for the past few years, especially with the construction of the Pan Borneo Highway [6]. Due to the increased number of road construction projects across the country, many trucks are exceeding the specified load limits by carrying additional weight to reduce transportation costs. Overloaded trucks can cause significant pavement deterioration. Additionally, some trucks may carry substantial loads that are not supported by the pavement structures as designed [7]. Therefore, there is research potential on the distress modelling and analysis of precast StormPav pavement for different wheel loads $(24 \mathrm{kN}, 26 \mathrm{kN}$ and $27 \mathrm{kN}$ ) to ensure that the pavement structures can withstand various wheel loading.

The purpose of this study is to conduct distress modelling on precast StormPav pavements using a variety of wheel loads to determine the pavement's performance. The analysis of the mechanistic behaviour for different structures of pavements (flexible pavement, rigid pavement, and precast StormPav pavement), and the mechanistic behaviour of precast StormPav pavements using different wheel loads $(24 \mathrm{kN}, 26 \mathrm{kN}, 27 \mathrm{kN})$ are performed.

\section{METHODOLOGY}

For this study, the performance of various road pavements, which includes flexible pavement, rigid pavement, and precast StormPav pavement will be evaluated under the wheel load of $27 \mathrm{kN}$. For precast StormPav pavement, it will be evaluated under various wheel loads $(24 \mathrm{kN}, 26 \mathrm{kN}$, and $27 \mathrm{kN})$. WINJULEA and MICHPAVE software were used to simulate distress fatigue cracking [8].

The pavement structures were designed using procedures from various transportation agencies,

Table 2 Wheel load information for 24-tonne truck such as JKR and AASHTO, using the same input parameters. Some constant criteria were used throughout the analysis for various sets of pavements to ensure the comparison between the result is valid. Table 1 shows the pavement design parameters properties that keep constant throughout the analysis.

Table 1 Pavement design parameters properties

\begin{tabular}{|c|c|c|c|}
\hline \multirow[b]{2}{*}{ Parameters } & \multicolumn{3}{|c|}{ Value } \\
\hline & Rigid & Flexible & $\begin{array}{r}\text { Precast } \\
\text { StormPav }\end{array}$ \\
\hline $\begin{array}{l}\text { Design Life } \\
\text { (years) }\end{array}$ & & 30 & \\
\hline $\begin{array}{l}\text { Structural number } \\
\text { (SN) }\end{array}$ & - & 3.0 & - \\
\hline $\begin{array}{c}\text { Terminal } \\
\text { Serviceability Index }\end{array}$ & & 3.0 & \\
\hline
\end{tabular}

The truck used in this research was a tandem axle (single axle drive dual tire rear) with a gross vehicle weight (GVW) of 24 tonnes, 26 tonnes, or 27 tonnes, as detailed in Table 2, Table 3, and Table 4 respectively. These 3 types of trucks are suited with 80R22.5 tires. The contact area is a function of tire pressure, wheel geometry, and axle load [8]. It can be represented by 2 semi-circles, which can be simplified as an equivalent rectangle as illustrated in Fig 1. The total simplified contact area is $0.54 \mathrm{~L} 2$, with $0.6 \mathrm{~L}$ of width and $0.9 \mathrm{~L}$ of length.

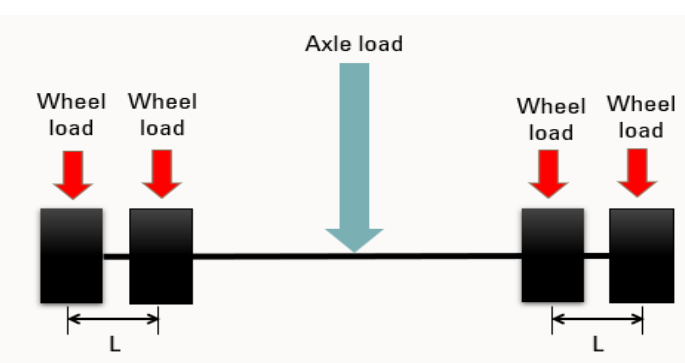

Fig.1 Wheel load configuration for tandem axle load used for analysis

\begin{tabular}{cccccc}
\hline Axle Group Load & $\begin{array}{c}\text { Axle Load } \\
(\mathrm{kN})\end{array}$ & $\begin{array}{c}\text { Number of wheels } \\
\text { per axle }\end{array}$ & $\begin{array}{c}\text { Wheel load } \\
(\mathrm{kN})\end{array}$ & $\begin{array}{c}\text { Tire Pressure } \\
(\mathrm{kPa})\end{array}$ & $\begin{array}{c}\text { Length (mm) } \\
\text { (Spacing between 2 } \\
\text { tires) }\end{array}$ \\
\hline $\begin{array}{c}\text { Single axle-single } \\
\begin{array}{c}\text { wheel } \\
\text { Tandem axle-dual } \\
\text { wheel }\end{array}\end{array}$ & 48 & 2 & 24 & 610 & 1760 \\
\hline
\end{tabular}


Table 3 Wheel load information for 26-tonne truck

\begin{tabular}{cccccc}
\hline Axle Group Load & $\begin{array}{c}\text { Axle Load } \\
(\mathrm{kN})\end{array}$ & $\begin{array}{c}\text { Number of wheels } \\
\text { per axle }\end{array}$ & $\begin{array}{c}\text { Wheel load } \\
(\mathrm{kN})\end{array}$ & $\begin{array}{c}\text { Tire } \\
\text { Pressure } \\
(\mathrm{kPa})\end{array}$ & $\begin{array}{c}\text { Length (mm) } \\
\text { (Spacing between 2 } \\
\text { tires) }\end{array}$ \\
\hline Single axle-single wheel & 52 & 2 & 26 & 610 & 1760 \\
Tandem axle-dual wheel & 104 & 4 & 26 & 610 & 346 \\
\hline
\end{tabular}

Table 4 Wheel load information for 27-tonne truck

\begin{tabular}{cccccc}
\hline Axle Group Load & $\begin{array}{c}\text { Axle Load } \\
(\mathrm{kN})\end{array}$ & $\begin{array}{c}\text { Number of wheels } \\
\text { per axle }\end{array}$ & $\begin{array}{c}\text { Wheel load } \\
(\mathrm{kN})\end{array}$ & $\begin{array}{c}\text { Tire } \\
\text { Pressure } \\
(\mathrm{kPa})\end{array}$ & $\begin{array}{c}\text { Length (mm) } \\
\text { (Spacing between } \\
2 \text { tires })\end{array}$ \\
\hline Single axle-single wheel & 54 & 2 & 27 & 610 & 1760 \\
Tandem axle-dual wheel & 108 & 4 & 27 & 610 & 346 \\
\hline
\end{tabular}

Flexible and rigid pavements are the most frequently used types of road pavement. There are numerous pavement designs that have been widely used in road construction, and this study will use the pavement design summarized in Tables 5 and 6, which includes the Poisson's ratio, thickness, and elastic modulus of each layer in the pavement

Table 5 Flexible pavement parameters

\begin{tabular}{cccc}
\hline Materials & $\begin{array}{c}\text { Poisson } \\
\text { Ratio }\end{array}$ & $\begin{array}{c}\text { Thickness } \\
\text { (mm) }\end{array}$ & $\begin{array}{c}\text { Elastic } \\
\text { Modulus }\end{array}$ \\
\hline $\begin{array}{c}\text { 14mm } \\
\text { Bituminous } \\
\text { Pavement }\end{array}$ & 0.40 & 50 & 2200 \\
$\begin{array}{c}\text { 20mm } \\
\text { Bituminous } \\
\text { Pavement }\end{array}$ & 0.40 & 125 & 2500 \\
$\begin{array}{c}\text { Cemented } \\
\text { Material }\end{array}$ & 0.20 & 150 & 2000 \\
Granular & & & \\
Material & 0.35 & 200 & 210 \\
$\begin{array}{c}\text { Subgrade, } \\
\text { CBR = 5\% }\end{array}$ & 0.45 & - & 50 \\
\hline
\end{tabular}

Source: Putri et al, 2020 [9]
Table 6 Rigid pavement parameters

\begin{tabular}{cccc}
\hline Materials & $\begin{array}{c}\text { Poisson } \\
\text { Ratio }\end{array}$ & $\begin{array}{c}\text { Thickness } \\
(\mathbf{m m})\end{array}$ & $\begin{array}{c}\text { Elastic } \\
\text { Modulus } \\
(\mathbf{M P a})\end{array}$ \\
\hline $\begin{array}{c}\text { Unreinforced } \\
\text { concrete slab } \\
\text { (Grade 30) } \\
\text { Concrete }\end{array}$ & 0.20 & 200 & 30000 \\
$\begin{array}{c}\text { Base } \\
\text { Lean Mixed } \\
\text { Concrete } \\
\text { Subgrade, } \\
\text { CBR = 5\% }\end{array}$ & 0.20 & 150 & 3000 \\
\hline Source: Putri et al, 2020 [9] & 0.45 & 125 & 2000 \\
\end{tabular}

The precast StormPav Pavement is made up of Grade 50 concrete. It consists of 3 sections, which are top cover, hollow cylinder, and bottom cover, with a total thickness of $0.45 \mathrm{~m}$. The top and bottom cover is in a hexagon shape, while the middle part is a hollow cylinder as shown in Fig 2. Table 7 shows the precast StormPav pavement parameters. The elastic modulus for the pavement was sourced from Mechanical Properties of Concrete and Steel Reinforcement $[9,10]$.

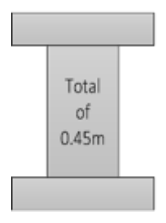

Top cover $=0.075 \mathrm{~m}$
Hollow Cylinder $=0.30 \mathrm{~m}$
Bottom Cover $=0.075 \mathrm{~m}$

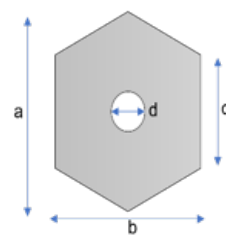

Dimension of Hexagon (Top \& Bottom cover)

$a=0.5 \mathrm{~m}$

$b=0.433 \mathrm{~m}$

$c=0.25 \mathrm{~m}$

$d=0.04 \mathrm{~m}$

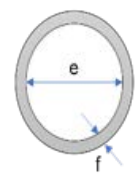

Dimension of Hollow Cylinder

$e=0.28 \mathrm{~m}$

$f=0.06 \mathrm{~m}$

Fig.2 Geometric design for precast StormPav pavement (Source: Putri et al, 2020 [9] 
Table 7 Precast StormPav pavement parameters

\begin{tabular}{cccc}
\hline Materials & $\begin{array}{c}\text { Poisson } \\
\text { Ratio }\end{array}$ & $\begin{array}{c}\text { Thickness } \\
(\mathbf{m m})\end{array}$ & $\begin{array}{c}\text { Elastic } \\
\text { Modulus } \\
\text { (MPa) }\end{array}$ \\
\hline Top Cover & 0.20 & 75 & 34500 \\
$\begin{array}{c}\text { Hollow } \\
\text { Cylinder }\end{array}$ & 0.20 & 300 & 34500 \\
$\begin{array}{c}\text { Bottom } \\
\text { Cover }\end{array}$ & 0.20 & 75 & 34500 \\
$\begin{array}{c}\text { Subgrade, } \\
\text { CBR }= \\
5 \%\end{array}$ & 0.45 & - & 50 \\
\hline \multicolumn{2}{c}{ Source: Putri et al, 2020 [9] } &
\end{tabular}

Source: Putri et al, 2020 [9]

WinJULEA and KENPAVE were used in this study to simulate a real-world scenario and determine the deflection, stress, strain, and stress of each layer of the pavement when subjected to traffic loading. The fatigue and rutting models described in Equations (1), (2), (3), and (4) are used to calculate the strain on the pavement caused by load repetition [7].

$N_{f}=f_{1} \varepsilon t^{*} f_{2} E_{1}{ }^{*} f^{3}$

Where:

$\boldsymbol{N}_{\boldsymbol{f}}=$ allowable number of load repetitions to prevent fatigue cracking from reaching a certain limit $(10-20 \%$ of the pavement surface area)

$\boldsymbol{\varepsilon} \boldsymbol{t}=$ tensile strain on the bottom of the asphalt layer

$\boldsymbol{E}_{\mathbf{1}}=$ elastic modulus of the asphalt layer

$\boldsymbol{f}_{\mathbf{1}}, \boldsymbol{f}_{\mathbf{2}}, \boldsymbol{f}_{\mathbf{3}}=$ regression coefficients

$\log \left(N_{2}\right)=\left[\frac{4.6786^{*} 9:}{4.4 ;<;}\right]$ where $S_{>}>0.55$

$N_{2}=\left[\frac{\text { B. }<\mathrm{C} ;}{9:{ }^{*} 4 . \mathrm{BD}<\mathrm{C}}\right]^{\mathrm{D} .<\mathrm{E} \text {; }}$ when $0.45 \leq S_{>} \leq 0.55$

Where:

$\left.S_{r}=S \& / 0.944 f \quad c f\right)\left(\frac{P L_{S F}}{4.45 F_{1}}\right)^{0.94}$,

the ratio of equivalent stress to PCC flexural strength

$\boldsymbol{S}_{\boldsymbol{e}}=$ equivalent stress (MPa)
$\boldsymbol{L}_{\boldsymbol{S} \boldsymbol{F}}=$ load safety factor

$\boldsymbol{f}_{\boldsymbol{c f}}=$ design characteristics flexural strength at 28

days (MPa)

$\boldsymbol{P}=$ axle group load $(\mathrm{kN})$

$\boldsymbol{F}_{\mathbf{1}}=$ load adjustment for fatigue (based on axle group):

- $\quad$ single axle single wheel $($ SAST $)=9$

- $\quad$ single axle dual wheel $(\mathrm{SADT})=18$

- $\quad$ tandem axle single wheel (TAST) $=18$

- $\quad$ tandem axle dual wheel (TADT) $=36$

- $\quad$ triaxle with dual wheel $($ TRDT $)=54$

$N_{>}=f_{\mathrm{B}} \varepsilon v^{\cdot 2 \mathrm{~W}}$

Where:

$\boldsymbol{N}_{\boldsymbol{r}} \quad$ = allowable number of load repetitions to prevent rutting from reaching a certain limit (0.5in.) $\boldsymbol{\varepsilon v}=$ compressive vertical strain on the surface of the subgrade

$f_{\mathrm{B}}, f_{\mathrm{C}}=$ regression coefficients

\section{RESULTS}

Equivalent Single Axle Load (ESAL) refers to the summation of equivalent single axle loads used to combine mixed traffic to design traffic for the design period [1][7]. In this research, the vehicle used is 24-tonne, 26-tonne, and 27-tonne truck. The wheelbase of the vehicles is the combination of a drive axle (single axle) and a tandem axle. Table 8 shows the axle load equivalency factor used, while Table 9 shows the calculation of ESAL for each pavement type for a 24-tonne, 26-tonne, and 27- tonne truck.

Table 8 Axle Load Equivalency Factors

\begin{tabular}{ccccc}
\hline Axle & \multirow{2}{*}{ Load } & \multicolumn{3}{c}{ Axle Load Equivalent Factor } \\
Group & (kN) & Flexible & Rigid & StormPav \\
Load & & & & \\
\hline $\begin{array}{c}\text { Single } \\
\text { Axle }\end{array}$ & 44.5 & 0.168 & 0.088 & 0.080 \\
$\begin{array}{c}\text { Load } \\
\text { Tandem } \\
\text { Axle }\end{array}$ & 92.3 & 0.468 & 0.358 & 0.336 \\
Load & 115.7 & 0.517 & 0.636 & 0.618 \\
\hline
\end{tabular}

Source: AASHTO, $1993^{[1}$

Table 9 Calculation of total ESAL of each pavement type for a 24-tonne, 26-tonne, and 27-tonne truck

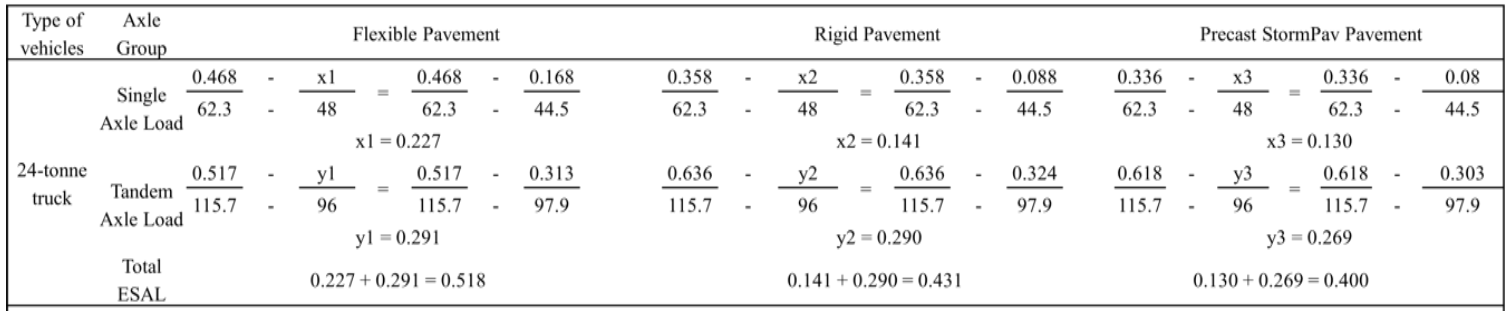


Table 9 continued

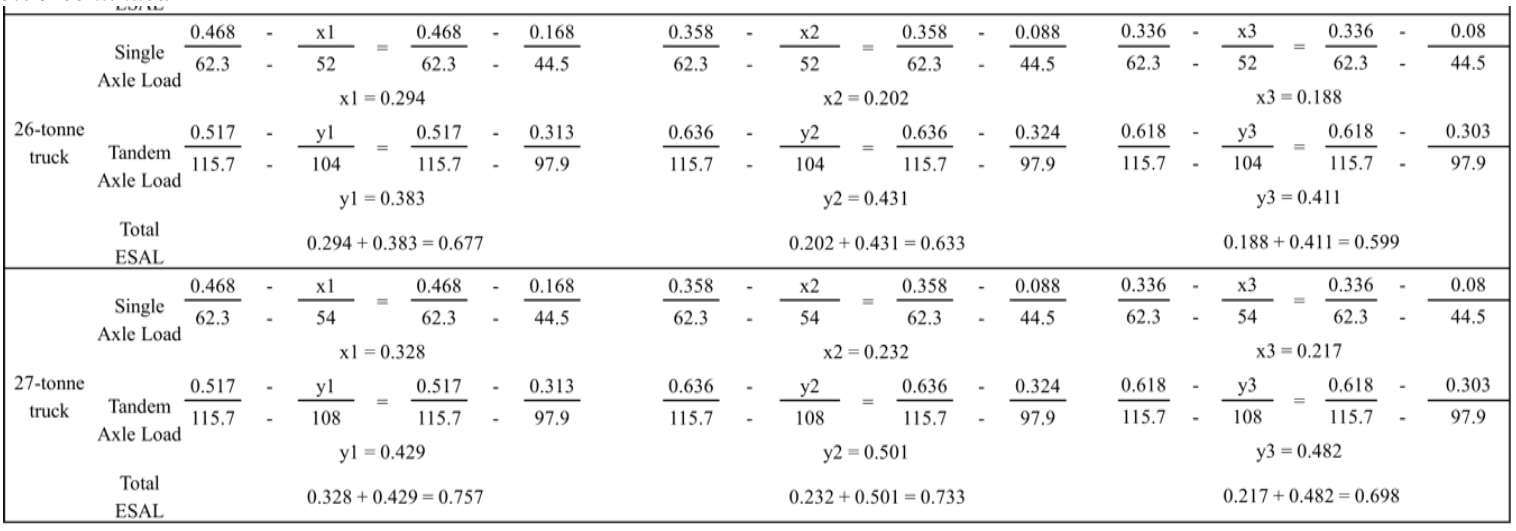

To obtain the total ESAL for each pavement type under design conditions, there are some assumptions made. It is assumed that there are 100 trucks per day, 6 days per week, and the road over a design life of 30 years. The total ESAL for each
The pavement under 24-tonne, 26-tonne, and 27tonne trucks are tabulated in Table 9 and while Table 10 shows the calculation of ESAL for each pavement type for the various truck.

Table 10 Calculation of total ESAL of each pavement type for a 24-tonne, 26-tonne, and 27-tonne truck

\begin{tabular}{|c|c|c|c|c|c|c|c|c|c|c|c|c|c|}
\hline Type of & Types of pavements & & & & & & & Total & $\mathrm{AL}$ & & & & \\
\hline \multirow{3}{*}{$\begin{array}{l}\text { 24- tonne } \\
\text { truck }\end{array}$} & Flexible Pavement & $6 / 7$ & $\mathrm{X}$ & 365 & $\mathrm{X}$ & 30 & $\mathrm{X}$ & 100 & $\mathrm{X}$ & 0.518 & $=$ & 486,381 & ESAL \\
\hline & Rigid Pavement & $6 / 7$ & $\mathrm{X}$ & 365 & $\mathrm{X}$ & 30 & $\mathrm{X}$ & 100 & $\mathrm{X}$ & 0.431 & $=$ & 404,855 & ESAL \\
\hline & Precast StormPav Pavement & $6 / 7$ & $\mathrm{X}$ & 365 & $\mathrm{X}$ & 30 & $\mathrm{X}$ & 100 & $\mathrm{X}$ & 0.400 & $=$ & 375,160 & ESAL \\
\hline \multirow{3}{*}{$\begin{array}{l}\text { 2b-tonne } \\
\text { truck }\end{array}$} & Flexible Pavement & $6 / 7$ & $\mathrm{X}$ & 365 & $\mathrm{X}$ & 30 & $\mathrm{X}$ & 100 & $\mathrm{X}$ & 0.677 & $=$ & 635,709 & ESAL \\
\hline & Rigid Pavement & $6 / 7$ & $\mathrm{X}$ & 365 & $\mathrm{X}$ & 30 & $\mathrm{X}$ & 100 & $\mathrm{X}$ & 0.633 & $=$ & 593,659 & ESAL \\
\hline & Precast StormPav Pavement & $6 / 7$ & $\mathrm{X}$ & 365 & $\mathrm{X}$ & 30 & $\mathrm{X}$ & 100 & $\mathrm{X}$ & 0.599 & $=$ & 562,030 & ESAL \\
\hline $\begin{array}{l}\text { 2\%-tonne } \\
\text { truck }\end{array}$ & Precast StormPav Pavement & $6 / 7$ & $\mathrm{X}$ & 365 & $\mathrm{X}$ & 30 & $\mathrm{X}$ & 100 & $\mathrm{X}$ & 0.698 & $=$ & 655,466 & ESAL \\
\hline
\end{tabular}

When a heavier truck passes through a similar pavement structure, the total ESAL increases as well. As a result, only the wheel load of $27 \mathrm{kN}$ (which provides the highest total ESAL) will be used in this research for the distress modelling and analysis of flexible and rigid pavements, while the precast StormPav pavement will use wheel loads of $24 \mathrm{kN}, 26 \mathrm{kN}$, and $27 \mathrm{kN}$. From the distress modelling, the result analysis will be done based on the comparison of various pavement for $27 \mathrm{kN}$ wheel load, and the comparison of various wheel loads for precast StormPav pavement. When there is a similar cyclic traffic loading acting on the top of the pavement, precast StromPav pavement has the lowest value for total ESAL, which is 655,466, compared to the flexible pavement (total
ESAL $=710,372$ ) and rigid pavement (total ESAL=688,061). Generally, flexible pavement is applied in layers, which have the weakest layer at the bottom, such as granular material, while more durable materials on the top layer, such as the bituminous layer, to ensure the structural integrity and adaptability of the entire structure. The top layer is not entirely load-bearing and resulted in the pavement more structurally and less collapsing under heavyweight [7]. For rigid pavement, it has high flexural strength compared to flexible pavement. It is no grain to gain load transferring as the top layer of the concrete will absorb the most pressure and weight from traffic. Therefore, the rigid pavement has a lower total ESAL compared to flexible pavement. Besides, it can be noticed that precast 
StormPav pavement has a slightly lower value for total ESAL compared to the rigid pavement as Precast StormPav uses concrete with Grade 50 which has higher flexural strength, compared to the rigid pavement made with concrete with Grade 30.

Distresses in road pavements can occur as a result of deflection caused by excessive loading from heavy vehicles acting on the top of the pavement [2]. The maximum deflections can be determined from the distress modelling with WinJULEA software. Table 11 shows detail of the tandem axle dual wheel used for this study. By using WinJULEA software, the deflection value for each type of pavement under various wheel loads is obtained and the displacement of each layer of the pavement structure is shown in Figure 3

Table 11 Detail of tandem axle dual wheel

\begin{tabular}{cc}
\hline Aspect & Dimension \\
Tire diameter & $1044 \mathrm{~mm}$ \\
Tire Size & $295 \mathrm{~mm}$ \\
Dual Tire Spacing (centre-to-centre) & $346 \mathrm{~mm}$ \\
Rear Axle & $1855 \mathrm{~mm}$ \\
\hline
\end{tabular}
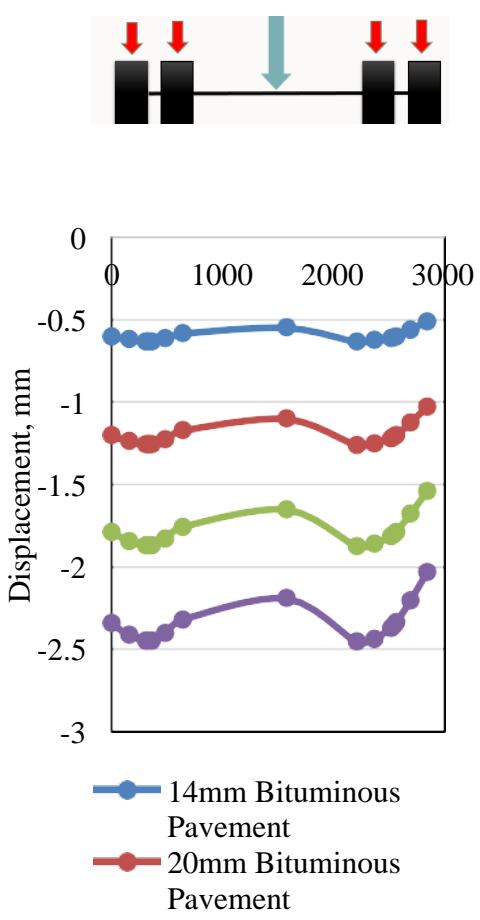

(a)
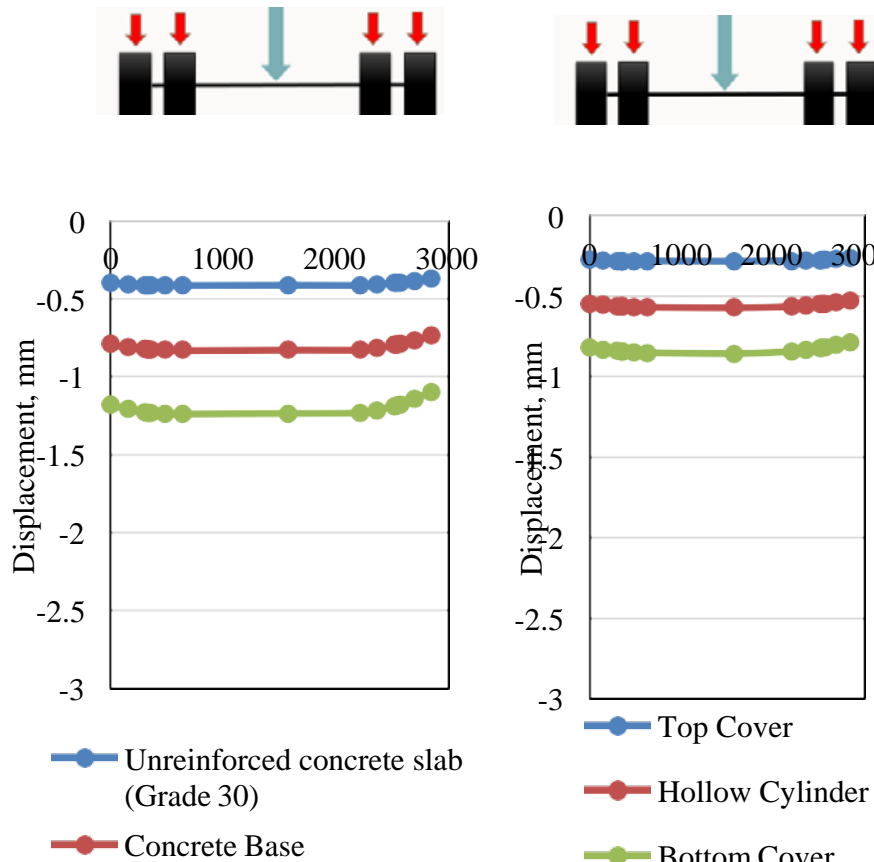

(b)

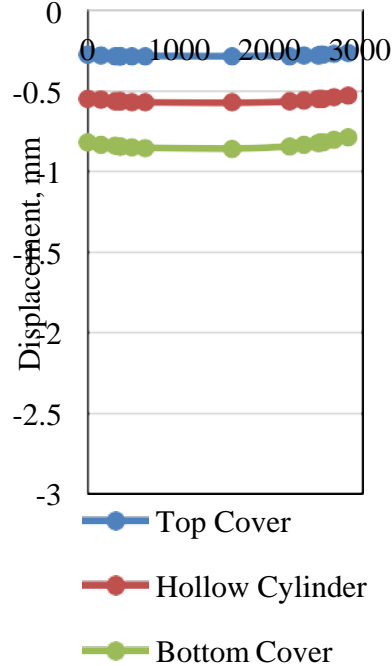

(c)

Fig.3. Surface deflection in the various layer for various pavements under wheel load 27kN. a) Flexible Pavement, b) Rigid Pavement, c) StormPav Pavement

Table 12 Total deflection of the precast StormPav pavement for various pavement

\begin{tabular}{ccc}
\hline $\begin{array}{c}\text { Types of } \\
\text { pavements }\end{array}$ & $\begin{array}{c}\text { Maximum } \\
\text { deflection } \\
(\mathrm{mm})\end{array}$ & $\begin{array}{c}\text { Percentage } \\
\text { of reduction } \\
(\%)\end{array}$ \\
\hline $\begin{array}{c}\text { Flexible } \\
\text { Pavement }\end{array}$ & -2.45 & 0 \\
Rigid Pavement & -1.24 & 49.46 \\
$\begin{array}{c}\text { Precast } \\
\text { StormPav } \\
\text { Pavement }\end{array}$ & -0.86 & 65.11 \\
\hline
\end{tabular}

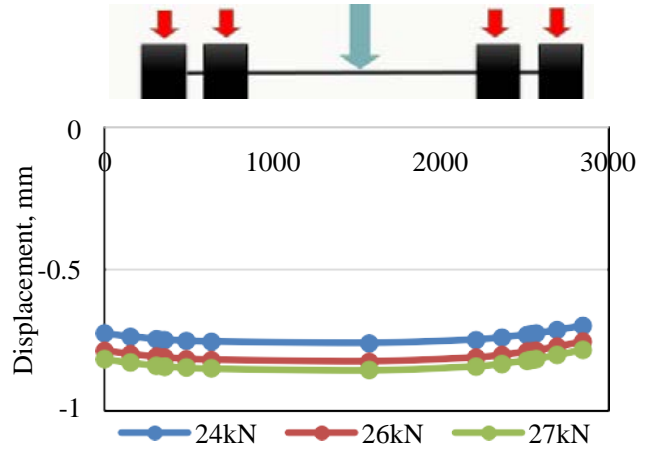

Fig 4 Total deflection of precast StormPav pavement for various wheel loads 
Among the types of pavements, precast StormPav pavement has the least deflection value compared to the flexible and rigid pavement. As shown in Table 12, the maximum deflection of rigid pavement is $1.24 \mathrm{~mm}$, which is $49.46 \%$ lesser than the maximum deflection of flexible pavement $(2.45 \mathrm{~mm})$. Precast StormPav has the lesser maximum deflection of $0.86 \mathrm{~mm}$, which had reduced $65.11 \%$ compared to the flexible pavement, as precast StormPav pavement has the largest elastic modulus compared to the flexible pavement and rigid pavement.

The total displacement of precast StormPav pavement in the $\mathrm{z}$-direction under $24 \mathrm{kN}, 26 \mathrm{kN}$, and $27 \mathrm{kN}$ of wheel loads are depicted in Figure 4, and the total deflection value for precast StormPav pavement under various wheel loads is depicted in Table 13, respectively. The data obtained show that the deflection value increases slightly when there is a heavier truck acting on top of the structure. From Table 13, when there is cyclic traffic loading from a 24-tonne truck, the total deflection is $0.761 \mathrm{~mm}$. When there is, cyclic traffic loading from a 26tonne truck, the total deflection only increases $0.064 \mathrm{~mm}(8.345 \%)$, which has a value of $0.825 \mathrm{~mm}$. This is because precast StormPav pavement is made up of concrete grade 50, which can resist heavier loading.

Table 13 Total deflection of the precast StormPav pavement for various wheel load

\begin{tabular}{cccc}
\hline $\begin{array}{c}\text { Types of } \\
\text { vehicles }\end{array}$ & $\begin{array}{c}\text { Total } \\
\text { deflection } \\
(\mathrm{mm})\end{array}$ & $\begin{array}{c}\text { Change in } \\
\text { deflection } \\
(\mathrm{mm})\end{array}$ & $\begin{array}{c}\text { Percentage } \\
\text { increases of } \\
\text { the } \\
\text { deflection } \\
\text { value }(\%)\end{array}$ \\
\hline $\begin{array}{c}\text { 24-tonne } \\
\text { truck } \\
\begin{array}{c}\text { 26-tonne } \\
\text { truck }\end{array}\end{array}$ & 0.761 & 0 & 0 \\
$\begin{array}{c}\text { 27-tonne } \\
\text { truck }\end{array}$ & 0.825 & 0.064 & 8.34 \\
\hline
\end{tabular}

Table 14 Allowable Number of Repetitions to Rigid Fatigue

\begin{tabular}{cc}
\hline Types of pavements & $\begin{array}{c}\text { Repetitions to Rigid } \\
\text { Fatigue }\end{array}$ \\
\hline Flexible pavement & $1.32 \times 10^{9}$ \\
Rigid pavement & $5.28 \times 10^{11}$ \\
Precast StormPav Pavement & $5.43 \times 10^{11}$ \\
\hline
\end{tabular}

According to Table 14, the maximum allowable number of load repetitions to prevent fatigue cracking from exceeding a certain threshold (10 $20 \%$ of the pavement surface area) increased as the type of pavement changed from flexible to rigid to precast StormPav. The highest value is precast StromPav pavement, which has higher flexural strength and can withstand more stresses on top of the structure.

\section{CONCLUSIONS}

From this study, the following conclusions can be made:

- The total ESAL is found to increase when a heavier truck passes through the pavement. When the same loading is applied to the top of each pavement, the total ESAL of the precast StromPav pavement is the lowest when compared to the flexible and rigid pavements.

- Flexible pavement, rigid pavement, and precast StormPav pavement will undergo deflection when there is loading acting on top of the pavement. Among the types of pavements, the maximum deflection of rigid pavement is $1.24 \mathrm{~mm}$, which is $49.46 \%$ lesser than the maximum deflection of flexible pavement $(2.45 \mathrm{~mm})$. Precast StormPav has the lesser maximum deflection of $0.86 \mathrm{~mm}$, which had reduced $65.11 \%$ compared to the flexible pavement, as precast StormPav pavement has the largest elastic modulus compared to the flexible pavement and rigid pavement. Besides, the deflection value increases slightly when there is a heavier truck acting on top of the structure. When there is cyclic traffic loading from a 24-tonne truck acting on the top of the precast StormPav pavement, the total deflection is $0.761 \mathrm{~mm}$ and increases $0.064 \mathrm{~mm}$ $(8.345 \%)$ when there is cyclic traffic loading change to 26-tonne truck, as precast StormPav pavement is made up of concrete grade 50, which can resist to heavier loading.

- From flexible pavement to the rigid pavement and precast StormPav pavement, the maximum allowable number of load repetitions to prevent fatigue cracking from reaching a certain limit ( $10-20 \%$ of the pavement surface area) had increased. The highest value is precast StromPav pavement, which has higher flexural strength and can withstand more stresses on top of the structure.

Therefore, it can conclude that the precast StormPav pavement is an alternative to replace flexible and rigid pavement as it required short construction times and less damage when heavier loading acts on it.

\section{RECOMMENDATION}

In this study, the wheel loads are assumed equally divided among the number of wheels. 
However, the actual wheel load at each point might differ. Besides, the wheel loads might have slightly different from the ones used in software analysis as there might have overweight trucks. The tire pressure for the wheel of 24-tonne, 26-tonne, and 27-tonne trucks are assumed to be the same for this study, which might not the same in the real scenario.

\section{ACKNOWLEDGMENTS}

This research was supported by the Engineering Faculty of Andalas University and conducted at the Faculty of Engineering, Universiti Malaysia Sarawak, Sarawak, Malaysia under Final Year Project for session 2020-2021.

\section{REFERENCES}

[1] American Association of State Highway and Transportation Officials. (1993). In AASHTO Guide for Design of Pavement Structure. Washington: American Association of State Highway and Transportation Officials.

[2] Min C. H., Jyh D. L., and Chih F. H., Automatic Image Recognition of Pavement Distress for Improving Pavement Inspection, International Journal of Geomate, Vol.19, Issue 71, 2020, pp. 242 - 249

[3] Behiry, E. (2012). Fatigue and rutting live in flexible pavement. Ain Shams Engineering Journal, 367-374

[4] Frisky R. A. M.C., and Bambang S. S., Fatigue Life Analysis of Rigid Pavement Structure with Pervious Concrete Base Layer Using 2d Finite Element Method, International Journal of Geomate, 2019 Vol.17, Issue 63, pp. 263 - 270

[5] Martin Š., Rudolf U., Martin L., Vilém K., and Tomáš K., Vegetation Filtering of a Steep Rugged Terrain: The Performance of Standard
Algorithms and a Newly Proposed Workflow on an Example of a Railway Ledge, Technical Note, Remote Sens. 2021, 13, 3050. https://doi.org/10.3390/rs13153050

[6] Povera, A. (18 December 2016). Pan Borneo Highway: On the road to success. Retrieved from

https://www.nst.com.my/news/2016/12/19777 4/pan-Borneo-highway-road-success.

[7] Huang, Y. (2004). Pavement Analysis and Design. New Jersey: Pearson Prentice Hall.

[8] Tougeer, \& Qureshi. (2019). Analysis and Design of Flexible Pavement Using EmpiricalMechanistic Based Software(KENPAVE). Retrieved from https://www.researchgate.net/publication/3315 33199_Analysis_and_Design_of_Flexible_Pa vement_Using_Empirical-

Mechanistic_Based_Software_KENPAVE

[9] Putri, E.E., Yuliet, R., Seng, C., Mannan, M., Silas, L., Ibrahim, W., . . . Tasnim, S. (2020). StormPav Green Pavement an environmentally friendly pavement. Retrieved from https://doi.org/10.1051/e3sconf/20201560500 8

[10] Gu, X., Jin, X., \& Zhou, Y. (2016). Basic Principles of Concrete Structures. Springer: Spinger-Verlag Berlin Heidelberg

[11] Bradshaw, L. (12 February 2019). Asphalt Paving. Retrieved from What is the difference between flexible pavement and rigid pavement: https://suresealpavement.com/differenceflexible-pavement-rigid-pavement/

Copyright (C) Int. J. of GEOMATE All rights reserved, including making copies unless permission is obtained from the copyright proprietors. 